\title{
THOUGHTS ABOUT THE HISTORIOGRAPHY OF VERACITY OR "TRUTHFULNESS" IN UNDERSTANDING AND TEACHING HISTORY IN SOUTH AFRICA ${ }^{1}$
}

\author{
DOI: http://dx.doi.org/10.17159/2223-0386/2016/n15a3 \\ Elize $S$ van Eeden \\ North-West University (Vaal Triangle Campus) \\ elize.vanEeden@nwu.ac.za
}

\begin{abstract}
Few historians today would argue that we write the truth about the past. It is generally recognised that written history is contemporary or present orientated to the extent that we historians not only occupy a platform in the here-and-now, but also hold positions on how we see the relationship between the past and its traces, and the manner in which we extract meaning from them (Alun Munslow, 2006:118).
\end{abstract}

\section{Abstract}

Debating the understanding and use of historical content as fact andlor fiction in publications has come a long way in the science of History (historiography). Arthur Marwick for example, in "The new nature of history, knowledge, evidence, language" provides, amongst others, insight into aspects of fact and fiction in writing (and certainly so in teaching) as part of the "eight battles" historians usually face. ${ }^{2}$ To what lengths historians and educators of History in South Africa have contributed to voices and views in research on features of fact and fiction (concepts also associated with "truth" or truthfulness "cum veracity") regarding the country's past will be the key focus of the paper. Eight South African journals have been scrutinised for thoughts and notions of academia (as authors of articles) regarding their way of going about with particular histories and their associations with veracity, or their criticism against past histories because of an absence or lack of veracity. The general stand of the author is that educators of History must also be sensitised to the realities of onesided factual exchange or a sense of fiction-creating in past knowledge, used as sources in Further and Higher Education and Training environments. The quest is that educators must also sensitise their students of History and Education History to be sufficiently informed and efficiently prepared when reading and using sources related to History in the classroom. Critical reading seems to be a way to become prepared to address the level of veracity of published historical research. Hands-on guidance towards critical reading will be briefly shared in the last part of the discussion.

1 T Haydn, "The importance of the concept of veracity/truthfulness in history education", Paper presented and reworked: CISH XXIInd Congress, Session, 28 August 2015.

2 A Marwick, The new nature of History. Knowledge, evidence, language (UK Hampshire, Palgrave, 2001), pp. 334. 
Keywords: Veracity; Truthfulness; Critical reading History; Teaching History; Fact and fiction; South Africa.

\section{Introduction}

When delving into an aspect of historiography in History, one necessarily finds the fallible self at the centre of the activity - as Arthur Marwick ${ }^{3}$ puts it with reference to all historians: “...fallible human beings, known as historians". These imperfect beings have their way in research and in writing, in method and principle, in order to make "choices in the language they use". Equally so, these beings, while at work, do not only engage in battle with language and with what a proper articulation may be, but they also battle with their own past world and their current world view. Moreover, they also become involved in battles regarding one another's choices and thoughts. ${ }^{4}$ In the light of these realities, a discussion with regard to veracity or historical truthfulness as "dream" is debated in a discussion of the impressions of historians and other researchers writing about aspects of South Africa in eight scientific journals associated with the history of Southern Africa.

Apart from observing the views of historians with regard to truth and truthfulness in science, another reality that will always remain part and parcel of History concerns the views of the past as reflected or perceptionalised by politicians and communities in general. A typical example will be the opinion of the post Second World War Russian leader Nikita Khrushchev, who is said to have stated that:" "Historians are dangerous people; they are capable of upsetting everything". ${ }^{6}$ It appears that this was a statement used by one Christina Barnes in 2012, who wanted to know from students what it meant to them to study History. One of several students asked, responded by quoting Khrushchev's remark “... if a historian interprets something incorrectly, that could be dangerous". The student's opinion could also be associated with the historical profession's battle or struggle towards the production of a representative, truthful historical account of a past event - one that can be assessed as to whether it is based on fact or on fiction, is accurate, reliable, authentic, representative and legitimate, or as valid as time and source access

3 A Marwick, The new nature of history: Knowledge, evidence, language (UK, Lyceum Books Incorporated, 2001), pp. 334.

4 See discussion later on South African historians as viewed by K Harris, "Warring societies? Towards a community of historians HASA and SAHS (1956-2014)", Historia, 59(2), November 2014, pp. 355-368.

5 With acknowledgement to a C Barnes, 2012.

6 Anon., "What does it mean to study history?" (available at http://www.dpcdsb.org/NR/rdonlyres/EA81D42F53AD-4B4E-B061-D086615EF2FD/32808/WhatdoesitmeantostudyHistory.pdf), as accessed on July 2015. 
permits. ${ }^{7}$ Historians probably realise that the "battle" towards presenting a past as an absolute non-contestable piece, appreciated for its features of veracity will never be fully won. Yet there are ways to ensure progress towards best practice by means of developing a sensitivity to search for and to make use of a diversity of knowledge frameworks, in order to ensure inclusivity in past voices on issues and, equally so, to cultivate a habit of critical source reading.

To follow is an emphasis on the impressions of historians in South Africa regarding aspects concerning fact (a recovery of the "truth" or/and "truthfulness" as scientific enterprise) ${ }^{8}$ as well as fiction (meaning imaginary and not based on sufficient or reliable research) ${ }^{9}$ as contributions towards understanding and writing about South Africa. As general context with regard to the struggles of historians aspiring to truthfulness, the eight battlegrounds that Arthur Marwick discusses and which historians usually face (and no less do educators of history), also seem more than appropriate to mention. Lastly, some guidance is provided on how the educator of History could assess specific parts or sections of books and recent research articles in the classroom through a structured process of critical reading. Constructive exposure in this regard to learners and students may make them more sensitive to the historical battlegrounds and to ways in which they must approach History in order to be sensitised to academic truthfulness in classroom facilitations at all times.

\section{Considering Marwicks eight battlegrounds of History in dealing with veracity}

In their profession, historians (and history educators) constantly face battles (as coined by Arthur Marwick) ${ }^{10}$ when dealing with the past in processes of recording, understanding and presenting historical narratives as truthful, since it can be a complex maze and overwhelming to a mind aspiring to be a "responsible" historian. Equally so, historians also battle against each other on what precisely and how accurately the past should be recorded. Some of these inescapable battles closely related to debating the search for truthfulness are the following:

7 Compare with A Marwick, The new nature of history..., pp. 334.

8 Compare RF Berkhofer (Jr), Beyond the great story. History as text (USA, Harvard University Press, 1997), Preface, p. 73.

9 Compare the interesting discussion by GW Bowersock, Fiction as History: Nero to Julian (USA, University of California Press, 1994), preface, pp. ix-x.

10 A Marwick, The new nature of history..., pp. 334; A Munslow, Deconstructing history, 2 (London and New York, Taylor \& Francis), 2006, p. 118; P Veyne, Writing History: Essays on epistemology (Middletown, Wesleyan University Press, 1984), pp. 342. 


\section{- The metaphysical, nomothetic and ontological ${ }^{11}$}

In the metaphysical, Marwick states, there is a tendency to ponder on questions and jargons in questions posed "out-of-context". In the nomothetic, there is an implication of drawing a distinction between the theoretical and the speculative on the one hand and the purely empirical on the other hand. The ontological, on the other hand, reflects questions by human beings about the purpose of life, the ways in which societies develop and reasons for inequalities and oppressions.

Marwick is of opinion that a genuine historical approach in research and writing (method) must always be professional, non-metaphysical and sourcebased and differ regarding aim and language from the post-modernist metaphysical supporters. He states that: ${ }^{12}$

It is simply not the aim of historians to produce exciting, speculative, all embracing theories, or gigantic leaps of imagination utterly detached from evidence, and still less should they try to integrate their own researches into such speculations.

In turn Alan Munslow, a self-declared post-modernist deconstructive historian, ${ }^{13}$ differs from Marwick. He prefers to rather be in agreement with Paul Veyne's writing in 1984 on "Writing History, Essays on Epistemology", in which Veyne ${ }^{14}$ states that "a narrative in a root metaphor can also hold within itself a theory of the truth as a primary mechanism for coping with experience" (past and present). Munslow feels that one should begin with the historian's representation of the past first before commencing with the past. ${ }^{15}$ Marwick, according to Munslow, makes too little of the historian's own consciousness from which historical explanations are generated. So the ever on-going confrontation remains regarding the non-metaphysical as opposed to the metaphysical approach to historical narrative in which the writing of historical truthfulness (to be understood as "fact") remains in a battle with the imaginary or "fiction", which is still contested to this day.

\section{- Radical politics or just nibilism?}

Nihilism as a philosophical view that implies, amongst other things, that life is without objective or meaning; that gaining an all-inclusive knowledge is impossible and that "reality" (as, for example, reflected in History) does not

11 Ontology is regarded as a branch of philosophy known as metaphysics.

12 A Marwick, The new nature of history..., p. 6.

13 A Munslow, Deconstructing history..., p. 118.

14 P Veyne, Writing History: Essays on epistemology..., pp. 342.

15 A Munslow, Deconstructing history..., introductory pages. 
exist. ${ }^{16}$ Radical politics, on the other hand, as far as Marwick is concerned, means those who denote political principles as focus to alter social structures and value systems through revolutionary writing and/or ideas. This "change" implies working systematically towards changing a "bad bourgeois" society from their "language, values, culture and ideology". ${ }^{17}$ In History, no historical discussion is definite or final for Marwick. The "truthful" debate can always be qualified or corrected and political bias will be pointed out vigorously. Marwick adds that historians are not propagandists: "Their job" is to understand the past (or parts of it), to inform and not "to change the future".

\section{- The challenge of truthfulness in the cultural construction of knowledge}

Marwick feels that historians do not "construct" the past as such a word, amongst others, is the bedrock of "critical" and "cultural" theory, and "indentured" to the metaphysics. He asserts that historians should prefer more precise verbs and invest much more in explanations than in assertions when writing History. ${ }^{18}$ Munslow, however, differs in his critique, asserting that historians tend to construct "the" past, and that a deconstruction [thus history without a paradigm?] is the way in which: ${ }^{19}$

... the deconstructively self-reflexive and self-conscious historian may, while accepting it is she who authors the past, may feel it is possible to legitimately offer an interpretation which, although it does not claim to be the true narrative, is nevertheless a plausible rendering of it...

It is easy to go along with Munslow's view. Also that the meaning of sources is arbitrary, and equally so the "opaque character" of language, besides "the arbitrary and socially provided relationship between the signifying word and the concept it signifies". The importance of a past and a present narrative explanation in order to understand the present from the past (a past embedded in physical and ideological disruptions and chaos) could, according to Munslow, deliberate historians. Yet it is also necessary to see another meaning in the view of Hayden White's (1974 $)^{20}$ understanding of "constructing" history in the sense that the present cannot be understood

16 A Marwick, The new nature of history: Knowledge, evidence..., pp. 5-6.

17 A Marwick, The new nature of history: Knowledge, evidence..., p. 6.

18 A Marwick, The new nature of history: Knowledge, evidence..., pp. 6-8.

19 A Munslow, Deconstructing history, Institute of Historical Research, 1997 (available at http://sas-space.sas. ac.uk/4397/1/Deconstructing_History_by_Alun_Munslow__Institute_of_Historical_Research.pdf), as accessed on July 2015, pp. 1-4.

$20 \mathrm{H}$ White, "The value of narrativity in the representation of reality", Critical Inquiry, 7(1), 1980, pp. 5-27; JL Gorman, "Objectivity and truth in History", An Interdisciplinary Journal of Philosophy, 17(1-4), 1974, pp. 373-397. 
better if a research process to explore the past is not well framed and focussed. A lack of doing so can contribute to tendencies of concocting a past narrative relying on some "truth" as "fact" and some "fiction". Also, Marwick's point of warning is taken that care should be taken not to adopt a "gentlemanly" approach to postmodernist history too easily: ${ }^{21}$

Postmodernist theory, amongst others, encourages the view that it is impossible to write in a clear, straightforward way [and as "correct" or "representative" as possible with the most "reliable" approved sources by historians or researchers, than having done research on a particular topic].

Not doing so, Marwick states, will lead to post-modernist jargons, exaggerated metaphor and rhetoric. From Marwick's point of view this way of approaching the past is not perceived as truthful.

\section{- Language: The battle of History as a branch of literature?}

Language is viewed as a very important part of writing History in a truthful way. It remains a complicated medium of communication to ensure combinations of literary criticism, history and linguistics. Marwick states that "semantics and signification have preoccupied historians for generations" and that especially postmodernists state that language controls historians, which he opposes. ${ }^{22}$ As oppositional view within the postmodernist circles, Munslow, on the other hand states that: ${ }^{23}$

Written history is always more than merely innocent story-telling, precisely because it is the primary vehicle for the distribution and use of power. The very act of organising historical data into a narrative not only constitutes an illusion of "truthful" reality, but in lending a spurious tidiness to the past can ultimately serve as a mechanism for the exercise of power in contemporary society... Because today we doubt these empiricist notions of certainty, veracity and a socially and morally independent standpoint, there is no more history in the traditionalist sense, there are only possible narrative representations in, and of, the past, and none can claim to know the past as it actually was.

So the battle amongst historians on writing and research paradigms continue to further complicate the debate on how historical truthfulness is possible or impossible to establish. One may even question if in this possible absence or lack of a more inclusive utilising of past recounts in their variety (multi-disciplines) and diversity (several voices) will it not bring about more

21 A Marwick, The new nature of history..., pp. 18-20.

22 Compare J Goodman, “Editorial', Special issue on History as creative writing”, Rethinking History, 15(1), 2011 .

23 Compare the discussion of A Munslow, Deconstructing History..., pp. 14-16 in which he heavily relies on the thoughts of the Philosopher Michel Foucault. See also A Munslow, Deconstructing History..., p. 18. 
remoteness and distance if the need is for aspiring a sense of truthfulness in going about with historical narratives?

To what lengths historians and educators of History in South Africa have contributed to voices and views in research on features of fact and fiction (concepts also associated with "truth" or truthfulness cum veracity) regarding the country's past will be the key focus in the rest of the paper.

\section{Historians and history educators on truthfulness in South Africa's past}

In general, South Africa’s pre-1994 history and past presentations of its history - nationally and in curricula on school level ${ }^{24}$ - are viewed as controversial, ${ }^{25}$ Afrikaner-nationalist ${ }^{26}$ not as diverse and far away from allowing for notions of veracity or an acceptable truth. ${ }^{27}$ Though it may still take another decade or so to critically review the performances of publications in the post1994 years, the reality of time and the way it steers the historical decisions, selections and representations of the day seem an inescapable obstruction towards deliberated histories: Deliberated from the historian's fallible nature, the influence and impact of the space of origin and way of living as well as an enforced directive in education.

From a teaching-education perspective, the history community has recently been accused of scrupulousness and lack of integrity when using their sources. Also, the authority of the claims historians make have been said to be subject to critique by communities of professional practice. Haydn's frustration owing to historians not considering the necessity of veracity (as embedded in integrity, a respect for evidence, an open-mindedness, and an ethical passion for being reliable, legitimate, sincere and accurate at all times of writing) is shared. ${ }^{28}$ In order to understand the levels of dealing with truthfulness - also known as "veracity" - by historians on South Africa

24 ES van Eeden, "Studying History in South Africa; Reflections of yesterday to face, map and bridging diversity today and tomorrow", W Hasberg \& E Erdman (Eds), History Teacher Education. Global Interrelations (Germany, Wochenschau-Geschichte, 2015), pp. 225-258.

25 Compare K Smith, The changing past: Trends in South African historical writing (USA, Ohio, Southern Book Publishers, 1988), pp. 68-98; S Marks, S Trapido (Eds.), The politics of race, class and nationalism in twentieth century South Africa (London, Tourledge, 2014), pp. 1-70.

26 S Dubow, "Afrikaner nationalism, apartheid and the conceptualization of 'race", The Journal of African History, 33(2), July 1992, pp. 209-237.

27 Compare A Knapp, The past coming to roost in the present: Historicising History in four post-apartheid South African novels: André P Brink's Imaginings of Sand, Zakes Mda's Ways of Dying, JM Coetzee's Disgrace, and Phaswane Mpe's Welcome to our Hillbrow (Germany, Columbia University Press, 2014), pp. 17-34.

28 T Haydn, A Stephen, J Arthur, M Hunt, Learning to teach history in the secondary school: A companion to school experience (New York, Routledge, 2015), p. 104. 
(and especially South African historians) the research for this section of the discussion mainly involved selections of articles randomly chosen from eight of the most popular history journals in which South African historians publish or are editorially associated with. A search for contributions of articles in each journal related to an aspect of veracity and/or "truth" as well as references to "fact" and "fiction" was done selectively (and necessarily in an one-sided way). The selection was based mainly on whether an article title and/or the content related to or debated matters of "veracity", "truthfulness", and/or "fact" and "fiction" in writing histories nor about History as science.

\section{A view on South African historians' conceptual stand on veracity}

Veracity, for the sake of this discussion in a context of history research and history education in South Africa, is associated with working towards an intention of wanting to know what actually happened (a sense of "truth"), being "full of truth" in the way sources are utilised or knowledge is disseminated; a tendency towards being accurate in articulating research at all times; being open-minded, reliable, legitimate, exact, sincere and aspiring to trueness as part of a professional "honourability". Secondary vocabularies that come into play as being complementary to veracity will be to appreciate prismatic thinking, acknowledge multi-diversity and multi-disciplinary encounters and to be sensitised towards all knowledge offered as relics of the past. ${ }^{29}$ One can also exercise "historical veracity" only insofar as source access, knowledge and availability permit. For this reason, reinterpretations - no matter what paradigm or information may come to light - will always (and must always) remain part of the openness in historical research and debate.

In another authoritative dictionary source, the following is said of "truth": 30

The state of being the case: the body of real things, events and facts; a transcendent fundamental or spiritual reality; a judgement, proposition, or idea that is true or accepted as true; the body of true statements and propositions; the property (as of a statement) of being in accord with fact or reality. Truth, veracity, verity, verisimilitude: shared meaning element - the quality or property of keeping close to fact and avoiding distortion or misinterpretation.

29 Compare the Cambridge English Dictionary (available at dictionary.cambridge.org/dictionary/english/ veracity); The Free Dictionary (available at www.thefreedictionary.com/veracity) and the Oxford Dictionary (available at www.oxforddictionaries.com/definition/english/veracity), as accessed on January 2016.

30 Webster's New Collegiate Dictionary (London, 1975). 
In the past decade some authors have re-deliberated several shades of the concept of truth in History, ${ }^{31}$ that also from time to time - further in history, received some attention from academics. ${ }^{32}$ Judging by the number of articles found on concept-related words to veracity, or some alter-ego related words like truth and fiction or objectivity and subjectivity, it is possible to assume that debate about and quest for truthfulness in history and historical writing in journals on South Africa has not gone unnoticed: ${ }^{33} 34353637$

\begin{tabular}{|l|c|l|}
\hline Journal & \multicolumn{1}{|c|}{$\begin{array}{c}\text { Articles on } \\
\text { veracity-related } \\
\text { discourses }\end{array}$} & Comments \\
\hline Journal of Southern African Studies & 249 & $\begin{array}{l}\text { Only one historian considered the } \\
\text { possibility of veracity in research done. } \\
\text { Truth or truthfulness visible in fiction } \\
\text { contributions only (e.g. art, cinema and } \\
\text { literary contributions) }\end{array}$ \\
\hline South African Historical Journal & 171 & $\begin{array}{l}\text { More references to notions of veracity, } \\
\text { but the emphasis is more on using words } \\
\text { connected to assessing or endorsing the } \\
\text { "interpretation"; "reinterpretation" or } \\
\text { "misinterpretation" of veracity. Older } \\
\text { articles linger on the use, and sometimes } \\
\text { irresponsible use of "truth" in discussing } \\
\text { research done. }\end{array}$ \\
\hline New Contree & 176 & $\begin{array}{l}\text { The same notion as in the SAHJ is found, } \\
\text { except that a very focused publication on } \\
\text { fact and fiction was submitted by Kobus } \\
\text { du Pisani in the early 21 }\end{array}$ \\
\hline
\end{tabular}

31 The work that comes to mind are that of MG Murphey, Truth and History, 1 (New York, Sunny Press, 2009); E Paris, Long shadows: Truth, lies and history, 5 (USA, Bloomsbury Publishing, 2015).

32 Compare the writing of P Ricour, History and truth (USA, Northwestern University Press, 1965), pp. 15-40; H Putnam, Reason, truth and history (UK, Cambridge University Press, 1981), pp. 127-173.

33 In particular is pointed out Michael Wessels' article on "The /Xam narratives: Whose myths?", African Studies, 67(3), pp. 339-364.

34 See for example M Hugo and KW de Pauw, "Feite of fiksie - Freudiaanse fantasie en ' $n$ feministiese beeld van Susanna Smit", Historia, pp. 8-13; RA Laing, "Our South African (Afrikaner) heraldic heritage - A mythical creation?”, Historia, 49(1), May 2004, pp. 110-134.

35 Compare with S Leech, "New histories for a new millennium", Kleio [African Studies], 2001, 33(1), pp. 144155.

36 Though in existence since 1981 a thorough Google Scholar research is only possible as from 2006.

37 One recent critical view on past narratives is that of N Nieftagodien, "Youth in history, youth making history: Challenging dominant historical narratives for alternative futures", Yesterday \&Today, 6, December 2011, pp. 1-11. Elize van Eeden also produced some articles that could be considered. 


\begin{tabular}{|c|c|c|}
\hline Journal of African Studies & 114 & $\begin{array}{l}\text { A feature in some articles is the critical } \\
\text { contesting of truth and "truer" versions } \\
\text { which are necessarily possible in counter- } \\
\text { memory. A theoretical discussion of the } \\
\text { possibility or impossibility of historical } \\
\text { veracity appears to be a less contentious } \\
\text { debate in the JAC. }\end{array}$ \\
\hline Historia & 77 & $\begin{array}{l}\text { Examples of discussions under "fact and } \\
\text { fiction" are evident in articles identified } \\
\text { on contesting "truth" in history. }\end{array}$ \\
\hline African Historical Review & 36 & $\begin{array}{l}\text { Journal articles identified expose limited } \\
\text { discussion on "truth" as a theoretical } \\
\text { debate, and in particular the historian's } \\
\text { "ability" or "inability" to be "truthful". } \\
\text { Subaltern voices in postcolonial times are } \\
\text { part of some discussions, implicating the } \\
\text { acceptance of diverse voices of history. } \\
\text { An exposure of criticism on fantasies in } \\
\text { history (like writings on the Zulus) is said } \\
\text { to have a limited standing in the popular } \\
\text { market whose perceptions remain } \\
\text { statically embedded in past images of } \\
\text { history. }\end{array}$ \\
\hline $\begin{array}{l}\text { South African Journal of Cultural } \\
\text { History }\end{array}$ & 25 & $\begin{array}{l}\text { It appears that contributions mostly } \\
\text { accentuate film as medium to create } \\
\text { images of "truth". Also the value of } \\
\text { imagining in cultural history imposes on } \\
\text { history as discipline. }\end{array}$ \\
\hline $\begin{array}{l}\text { Yesterday\&Today } \\
\text { (since 2006) }\end{array}$ & 9 & $\begin{array}{l}\text { Theoretical contemplations on "historical } \\
\text { truthfulness" of histories displayed in } \\
\text { textbooks for various grades in schools } \\
\text { and those used in undergraduate studies } \\
\text { fall short, or are rather mechanically and } \\
\text { artificially assessed for the limitations } \\
\text { or efficiency in which the standard } \\
\text { curriculum is represented. More voice } \\
\text { should be added to how "truthfulness" } \\
\text { should be encouraged in master narratives } \\
\text { of South African history. }\end{array}$ \\
\hline
\end{tabular}

The comments in the table above serve as a general personal impression of the "contribution" made by scientific journals contributions related to South Africa's history, based on historical truth as point of debate. To follow are some pointers related to the two most prominently viewed journals, the 
JSAS and the SAHJ (and simply because space does not allow for a reflective discussion on each of the journals):

\section{Journal of Southern African Studies (JSAS)}

In line with its commitment, the JSAS covers a broader spectrum of continental researchers and also regularly publishes contributions on South Africa by non-South Africans. The Journal also accommodates other disciplines so that contributions in the arts and the languages strongly feature when there is emphasis on a search reflecting aspects of "truth" and "truthfulness" with which veracity is associated. ${ }^{38}$ The word "openness" also seems to be a favourable variant for writers to use when conducting research concerning "truth". ${ }^{39}$ Use of the word "veracity" hardly ever features in discussions. ${ }^{40}$

Historians skilfully tend to shy away from notions of having discovered the "truth" or trying to articulate truthfulness in the research themes being studied as will be done by writers of fiction, and perhaps writers endorsing a more postmodern stance of History. ${ }^{41}$ One particular example of contesting "truth" and even "more truthful" accounts for "numerous" accounts is voiced by Sheila Boniface Davies ${ }^{42}$ on Nongqawuse and the Great Xhosa CattleKilling Movement of 1856-1857 in South Africa.

Further in time, an acknowledged writer and expert regarding the South African War camps during the South African War of 1899-1902, Elizabeth van Heyningen, was the only historian identified in the JSAS contributions that reflected a sense of an imagining of the "truth" and "truthfulness" in her research observations, and by also utilising "veracity" as concept: ${ }^{43}$

While these ceremonies endorsed the grief of the families who had lost loved ones,women's testimonies validated the story of the camps themselves. The use of diaries and letters is a well-established source of historical

38 D Medalie, "A century later: New fictional representations of the Boer War", Journal of Southern African Studies, 30(2), June 2004, pp. 379-392.

39 Compare M Wade, "Myth, truth and the South African reality in the fiction of Sarah Gertrude Millin", Journal of Southern African Studies, 1(1), October 1974, pp. 91-10; NS Ndebele, "The rediscovery of the ordinary: Some new writings in South Africa”, Journal of Southern African Studies, 12(2), April 1986, pp. 143-157; C Coetzee, "All tickets please, or how cinema histories of South Africa can stop re-enacting the racialised past", Journal of Southern African Studies, 39( 3), September 2013, pp. 721-726.

40 S Marschall, "The virtual memory landscape: The impact of information technology on collective memory and commemoration in Southern Africa", Journal of Southern African Studies, 39(1), September 2013, pp. 193-205.

41 J Ferguson, "Modernist Narratives, Conventional Wisdoms, and Colonial Liberalism: Reply to a Straw Man", Journal of Southern African Studies, 20(4), December, 1994, pp. 633-640.

42 SB Davies, "Raising the dead: The Xhosa cattle-killing and the Mhlakaza-Goliat delusion", Journal of Southern African Studies, 33(1), March 2007, pp. 19-41.

43 E van Heyningen, "Costly mythologies: The concentration camps of the South African War in Afrikaner historiography”, Journal of Southern African Studies, 34(3), September 2008, pp. 495-513 (esp. p. 505). 
writing. Personal voices impart colour and directness, and diaries especially appear to lend veracity to the evidence. [Underlining by the writer, EvE]

Van Heyningen furthermore concluded from Emily Hobhouse's experience, as single-most prominent person associated with camps in South Africa, some notions of "integrity" (a concept also associated with "veracity") that underlies reasoning towards impressions of a trustworthy personality in Hobhouse: ${ }^{44}$

What mattered to Hobhouse was the repetition, the universality, of suffering; in this lay the veracity and the value of the [concentration camp inhabitants'] testimonies. [Underlining by the writer, EvE]

Van Heyningen concurs that the redeployment of a paradigm of suffering in post-apartheid times, as was the scenario with the three to four decade commemoration/remembrance of suffering of women and children in camps during the South African War of 1899-1902, may simply be reinforced in the present-day South Africa. In this regard she states as conclusion: ${ }^{45}$

It is doing no one a service, however, if an old mythology $y^{46}$ is redeployed to reinforce a new mythology of suffering, for new political purposes. Reconciliation and the building of a new nation are difficult projects; if founded on old mythologies they will not succeed.

The use of the words "numerous versions" (see Davies above) and "different interpretations", ${ }^{47}$ as well as intentions to avoid "subjectivity", ${ }^{48}$ or an inclination that past "contradictions" and "ambiguities" ${ }^{49}$ exist in a topic under study, become more visible in the articulation of discussions by historians, but sometimes traceable in contributions of other disciplines. ${ }^{50}$

Contrary to what the concept "veracity" wants to expose the reader to, visible tendencies rather were discussions on an acceptable fictionalised past or a

44 E van Heyningen, "Costly mythologies: The concentration camps of the South African War in Afrikaner historiography”, Journal of Southern African Studies, 34(3), September 2008, pp. 495-513 (esp. p. 506).

45 E van Heyningen, "Costly mythologies: The concentration camps of the South African War in Afrikaner historiography”, Journal of Southern African Studies, 34(3), September 2008, pp. 495-513 (esp. p. 513).

46 A version or understanding of what the truth maybe.

47 Compare JB Peires, "Paradigm deleted: The materialist interpretation of the Mfecane", Journal of Southern African Studies, (19)2, June 1993, pp. 295-313; G Paleker, "The state, citizens and control: Film and African audiences in South Africa, 1910-1948”, Journal of Southern African Studies, 2014, 40(2), pp. 309-323; S Nuttall, "City forms and writing the 'now' in South Africa", Journal of Southern African Studies, 30(4), December 2004, pp. 731-748, (esp. p. 743).

48 Compare S Kossew, "Re-reading the past: Monuments, history and representation in short stories by Ivan Vladislavic' and Zoe" Wicomb”, Journal of Southern African Studies, 36(3), September 2010, pp. 571-582.

49 Compare L Chisholm, "Education, punishment and the contradictions of penal reform: Alan Paton and Diepkloof Reformatory, 1934-1948”, Journal of Southern African Studies, 17(1), March 1991, pp. 23-42.

50 See as example in another discipline A van der Vlies, "On the ambiguities of narrative and of history: Writing (about) the past in recent South African literary criticism", Journal of Southern African Studies, 34(4), December 2008, pp. 949-961. 
national past concerned with nation-building practices in film as medium, ${ }^{51}$ and the government of the day having a firm control over its image and needs for marketing its image. ${ }^{52}$ Nation building as a way of utilising the past will always remain worlds apart from what History as discipline represents. ${ }^{53}$

Also, the experience and outcome of South Africa's Truth and Reconciliation Commission (TRC) in novels are abundantly discussed, and in critical ways ${ }^{54}$ in which it seems more acceptable to speak freely about a "truth" being visible or lacking. ${ }^{55}$ Andrew van der Vlies quoted a historian and a literarian in discussing the aspect of "truth" from within the TRC-hearings. In historian Deborah Posel's words, the past was understood by the TRC as: ${ }^{56}$

... the site of contending constructions and perspectives, each 'truthful' to those who proposed it, while it was also necessarily (because of the Commission's remit to produce as full a picture as possible of abuses of the apartheid era) a procession of 'facts', visible from the elevated and perspicacious vantage point of the Commission. Ostensible openness to multiple species of 'truth' made for 'a very wobbly, poorly constructed conceptual grid' [Underlining by the writer, EvE].

Poet and educationist Ingrid de Kok's impression of the TRC and truth corresponds in this instance well with Posel's thoughts: ${ }^{57}$

...that the TRC could not be expected to elicit or 'produce' the 'truth'; it was, rather, in the multiplicity of partial versions and experiences, composed and recomposed within sight of each other, that truth 'as a thing of this world', in Foucault's phrase, [would] 'emerge'. The archive, in other words, was necessarilyand inevitably - open to the future. [Underlining by the writer, EvE]

51 Compare M Simpson, "The experience of nation-building: Some lessons for South Africa", Journal of Southern African Studies, 20(3), Special Issue: Ethnicity and Identity in Southern Africa, September 1994, pp. 463-474; N Parsons, "Nation-building movies made in South Africa (1916-1918): IW Schlesinger, Harold Shaw, and the lingering ambiguities of South African Union", Journal of Southern African Studies, 39(3), September 2013, pp. 641-659.

52 G Paleker, "The state, citizens and control: Film and African audiences in South Africa, 1910-1948”, Journal of Southern African Studies, 2014, 40(2), pp. 309-323.

53 ES van Eeden, "The youth and school History - learning from some of the thinking of yesterday in South Africa”, Yesterday\& Today, 8, December 2012 (available at scielo.org.za), pp. 1-24; ES van Eeden, "Die jeug en Geskiedenis - vandag en gister, met verwysing na die Hertzog-era, Genl JBM Hertzoggedenklesing”, XXXX, Suid-Afrikaanse Akademie vir Wetenskap en Kuns, 2011, ISBN: 978-0-949976-81-9, pp. 1-35. English version available from author.

54 D Thelen, "How the Truth and Reconciliation Commission challenges the ways we use History", South African Historical Journal, 47(1), 2002, pp. 162-190.

55 S Kossew, "Re-reading the past...", Journal of Southern African Studies, 36(3), September 2010, pp. 571-582.

56 A van der Vlies, "On the ambiguities of narrative and of history: Writing (about) the past in recent South African literary criticism, Journal of Southern African Studies, 34(4) December 2008, p. 950. See the source itself: D Posel, “The TRC Report: What kind of history? What kind of truth?”, D Posel and G Simpson (eds), Commissioning the past: Understanding South Africa’s Truth and Reconciliation Commission (Johannesburg, Witwatersrand University Press, 2002), p. 150 [esp. pp. 147-72].

57 P Kaarsholm, "Inventions, imaginings, codifications: Authorising versions of Ndebele cultural tradition, Journal of Southern African Studies, 23(2), June 1997, pp. 243-258. 
That a search for the complete "truth" will always imply partiality seems to be a fait accompli, and not contested. ${ }^{58}$

Other discussions by researchers about South Africa (as in the JSAS) indirectly relate to "truthfulness" rather dominantly invest in reflecting on particular content for "truth". The tendency is then to rather utilise antonyms of "veracity" such as "inventions"; "imagining", 59 "stereotyping", "propaganda" and "subjectivity". ${ }^{00}$

\section{South African Historical Journal (SAHJ)}

The South African Historical Journal (SAHJ) is generally perceived as South Africa's most prestigious historical journal. ${ }^{61}$ The SAHJ is attached to the Southern African Historical Society who recently (1-3 July) hosted a conference at the University of Stellenbosch, Cape Town with the theme: "Unsettling stories and unstable subjects". From the conference invitation it is evident that the realities of past "complexities", a "multiplicity" of "memory and meaning" and encouragements debate "revision" are points of discussion and attention, but not necessarily explicitly aspiring to bluntly contest past notions of presenting "truths". Rather nicely, these contestations have been articulated by the Society in their call for papers, as: ${ }^{62}$

We historians must offer bold analyses based on a nuanced understanding of the complexities of change over time. Our stories can disrupt the complacent presentist narratives of the status quo, but while they have the power to unsettle, they - in turnare unsettled by each new generation of historians.

The "power to unsettle" is visible in several published articles of the SAHJ regarding a criticism on ways of having interpreted past narratives as not being complementary to "historical truthfulness". In a few discussions, like those

58 Compare with the impressions of P Gready, "The Sophiatown writers of the fifties: The unreal reality of their world”, Journal of Southern African Studies, 16(1), March 1990, pp. 139-164.

59 Compare P Kaarsholm, "Inventions, imaginings, codifications: Authorising versions of Ndebele cultural tradition", Journal of Southern African Studies, 23(2), June 1997, pp. 243-258.

60 L Saint, "Not Western: Race, reading, and the South African Photocomic", Journal of Southern African Studies, 36(4), December 2010, pp. 939-958; PR Anderson, "Satire and historical gainsaying in AG Bain's 'Kaatje Kekkelbek, or, Life among the Hottentots", Journal of Southern African Studies, 38(1), March 2012, pp. 217 232; E Sandon, "African Mirror: The life and times of the South African newsreel from 1910 to 1948 ", Journal of Southern African Studies, 39(3), September 2013, pp. 661-680; C Coetzee, "They never wept, the men of my race': Antjie Krog's Country of my skull and the white South African signature”, Journal of Southern African Studies, 27(4), December 2001.

61 See the home page of the journal (available at shttp://www.sahs.org.za/node/4), as accessed on January 2016.

62 See Call for Papers by the SAHS (available at https://networks.h-net.org/node/28765/discussions/49084/cfpsouthern-african-historical-society-1-3-july-2015), as accessed on October 2014. 
of Jessica Murray ${ }^{63}$ and Kobus du Pisani, ${ }^{64}$ the borderline between fact and fiction is pointed out. Because in both "fiction" and "fact" a close relatedness will exist, Murray points out the distinction between both by conferring the views of Jacques Derrida: ${ }^{65}$

Fiction is associated with the imagination; testimony is linked to experience or observation, while evidence carries connotations of something that can rationally and scientifically serve to indicate veracity... When there is proof, there is no need to appeal to be believed, since the existence of proof of a statement means that the veracity of that statement has been established.

As Murray rightly points out, the "difficulty with linking these concepts arises from the reality that they belong to apparently incompatible cognitive systems". Past impacts on South Africa's history, such as colonialism, apartheid ${ }^{66}$ and the varieties of contesting nationalisms, ${ }^{67}$ especially Afrikaner nationalism, ${ }^{68}$ are pointed out as stumbling blocks in creating a sense of "historical truthfulness" because of competing versions of the past. ${ }^{69}$

In essence, the argument for being "truthful" in historical writing, though a complex matter to its core, underlies notions of professional integrity and an approach in which diverse memories of a past trend or event is exposed. The work of some authors in the SAHJ supports diverse voices in topics under study. ${ }^{70}$ Bargueño's, ${ }^{71}$ for example, further suggests "more lexical precision, as well as the integration of transnational and indigenous voices into colonial and post-colonial archives to understand the colonial era..."

When having to comment on "truth" per se as concept, some authors mostly refer to the TRC era in a parenthetical manner to point out another matter of

63 J Murray, "Gender and violence in Cape slave narratives and post-narratives", South African Historical Journal, 62(3), 2010, pp. 447-448.

64 JA du Pisani, "Fact and fiction: Representations of the South African War in Afrikaans history writing and literature", New Contree, 45, September 1999, pp. 164-184.

65 J Murray, "Gender and violence in Cape slave narratives and post-narratives", South African Historical Journal, 62(3), 2010, pp. 447-448.

66 L Witz \& C Hamilton, "Reaping the whirlwind: The Reader's Digest illustrated History of South Africa and changing popular perceptions of History”, South African Historical Journal, 24(1), 1991, pp.185-202.

67 Compare L van Vuuren, "The many myths of Laurens van der Post: Van der Post and Bushmen in the television series Lost World of Kalahari (1958)", South African Historical Journal, 48(1), 2003, pp. 47-60. On p. 51 critique is given on the highly subjective stand in the myths and mythical interpretations of the past as for example created by the literarian Laurence van der Post regards the Bushmen in Lost World..

68 FA Mouton, "AN Pelzer: A custodian of Afrikanerdom”, South African Historical Journal, 37(1), 1997, pp. 133155 .

69 R Greenstein, "History, historiography and the production of knowledge, South African Historical Journal, 32(1), 1995, pp. 217-232 (esp. p. 225).

70 S Byala, "Museum Africa: Colonial past, postcolonial present", South African Historical Journal , 65(1), 2013, pp. 90-104 (esp. p. 103); DP Bargueño, "Imperial discontents: A review essay", South African Historical Journal, 63(4), December 2011, pp. 594-615.

71 DP Bargueño, "Imperial discontents: A review essay", South African Historical Journal, 63(4), December 2011, pp. 594-615. 
discussion. ${ }^{72}$ Other historians from other parts of Africa, who have published in the SAHJ, tend to be more frank in their reference to the achievability of "truth" (though still with caution, and employing inverted commas): ${ }^{73}$

The re-appropriation and revalorisation of the African past, of its history and its memory formed a crucial part of the 'African Renaissance' vision. There was a will to establish 'the truth' about the pre-colonial and colonial past and to restore and acknowledge African contributions to human civilisation... [Underlining by the writer, EvE].

Reading African and South African history as "truths" coming from other continents and countries have lately become another point of critical debate. ${ }^{74}$ Temu ${ }^{75}$ for example, notes:

Of what relevance is the history produced in the Euro-American academy to Africa? How do we judge such histories authored by outsiders, histories that are produced for an audience that is not Africa, histories which refuse to engage or converse with the very people who are actors in that history? Who validates or legitimises a history that is uprooted from its source to be presented elsewhere as the story of the 'other'? Who determines what constitutes an acceptable research topic and on what basis are such topics selected? To pose these questions is to enter the terrain of knowledge production and the politics associated with such an enterprise.

Processes of "knowledge production" and some apparent "agenda politics" behind productions are other complexities that make it difficult to attach "historical truthfulness" to research and writing at random. ${ }^{76}$ In this regard, the Floridian Luise White's remarks in a keynote address at an SAHS conference in South Africa some years ago provides insight on the non-negotiable responsibility of historians to adhere to moral universals when it comes to reflecting truthfulness in research: ${ }^{77}$

... One of the problems with current [2000] debates about history writing is that they're reified ten and twenty-year old practices around truth and evidence in ways that are simply inaccurate. The truth historians have understood since the 1960 s was itself fractured and partial. The truth of social history was categorically

72 Compare C Hamilton, "Forged and continually refashioned in the crucible of ongoing social and political life: Archives and custodial practices as subjects of enquiry”, South African Historical Journal, 2013, 65(1), pp. 1-22; H Sapire, Township histories, insurrection and liberation in late apartheid South Africa, South African Historical Journal, 65(2), pp. 167-198.

73 S Molins Lliteras, "From Toledo to Timbuktu: The case for a biography of the Ka'ti archive, and its Sources", South African Historical Journal, 65(1), pp. 105-124.

74 L White, "The most telling: Lies, secrets, and history", South African Historical Journal, 42(1), 2000, pp. 11-25.

75 A Temu, "Not telling: African history at the end of the millennium", South African Historical Journal", 42(1), pp. $2-10$.

76 See productions on South Africa such as F Hale, "Khoi Khoi culture refracted through a German prism: Christian Ludwig Willebrand's reconstruction in historical context”, South African Journal of Cultural History, 19(2), November 2005.

77 Compare L White, "The most telling: Lies, secrets, and history, South African Historical Journal, 42(1), 2000, pp. 11-25 (esp. pp. 7, 13). 
different from the truth based on the moral universals; it was a belief that individual experiences were the bedrock of historical evidence The project of social history was to render accurate the experiences of all subjects; the historical narrative would change and become more representative by inclusion.

We all know the drill, no national narrative without women, no political narrative without trade unionists and casual labourers, etc., etc. Such a project seriously undermined the idea that truth was a matter of moral universals, so that the history of the nation didn't look the same when all groups were included, the history of labour wasn't the same when you included prostitutes and pickpockets. Cultural historians have argued that the ways that this history looked different was an historian's construct... [Underlining by the writer, EvE].

Complexities in "doing history" will remain a transnational issue, and how to deal with sources and interpret them in order to arrive at an ultimate interpretation as "historical truthfulness" will remain a challenge, as was pointed out by White: ${ }^{78}$

But where does this leave us? If everyone is interpreting, how can we possibly know where sources' interpretation end and an ambitious historian's interpretation of the past begins? How do we know who to trust? And I think this is part of a professional crisis that is about the constitution of the profession - one form it takes is concerns over the nature of truth and evidence. When history and the uses of the past were primarily the concern of one class, one race, and one gender, there was great latitude about the use of evidence. Most of the great nineteenth-century historians never touched what you and I would consider primary sources, and they were concerned with telling a story with a moral rather than letting archives dominate their analysis [Underlining by the writer, EvE].

Thinking of "interpretation" as vocabulary (according to White) to be discreetly and directly associated with searching for "historical truthfulness", several contributions in the SAHJ deal with either matters of "diverse interpretations" as a requirement, "misinterpretations" or misrepresentations in past publications ${ }^{79}$ and/or the need for (and critical discussion of) "reinterpretations". ${ }^{80}$ Apart from "truth" as an abundantly used concept (and not necessary in the context of understanding for the purpose of this discussion), an author's convenient variant seems to be some or other "interpretation"

78 L White, “The most telling: Lies, secrets, and history", South African Historical Journal, 42(1), 2000, pp. 11-25 (esp. p. 13).

79 Compare L Kriel, "Colin Rae's Malaboch: The power of the book in the (mis)representation of Kgaluši Sekete Mmalebôhô”, South African Historical Journal, 46(1), 2002, pp. 25-41.

80 S Meintjes, "The Mfecane colloquium: Impressions”, South African Historical Journal, 25(1), 1991, pp. 173176. 
like "radical interpretation" 81 and progressing towards a "narrative truth". ${ }^{82}$

Source criticisms of South Africa's past also reflect a notion of determining who is "truthing" and who is lying, and sometimes even originate from the political front. A recent example is the South African Democracy Education Trust's publication titled The road to democracy in South Africa, Volume 1:1960-1970 in which former South African President, Mr Thabo Mbeki, did the foreword quite carefully (but perhaps not well-articulated enough on "the truth") as he states :83

The text will compensate for the "paucity of historical records chronicling the arduous and complex road" to South Africa's democratic settlement, the editors promise. "New insight" into the "operation of liberation movements" will result from "untapped documentary sources" and "the voices of scores of liberation veterans". In using such evidence we will arrive "much closer to the 'truth' than history books" (pp. vii-xix) that lack such testimony... [Underlining by the writer, EvE]

Another example, though over-abundantly lamented on, is by politician Dr Gatsha Buthelezi on what has historically been produced about King Shaka. Buthelezi's view is expressed by historian Carolyn Hamilton: ${ }^{84}$

$\mathrm{He}$ [Inkatha leader Gatsha Buthelezi] also criticized as 'pathetic' the writings of historians who relied on the texts of Isaacs and Fynn as sources for the period and described their endeavours as attempts 'to fornicate with the truth' [Underlining by the writer, EvE].

Mersham $^{85}$ also articulates a questioning of "truth" in his introduction to the Shaka topic and questions the historical veracity of mass media images. He notes:

The immediacy and apparent truth of the image confers a historical veracity on the material presented, creating for the viewer an easily digestible, but often misleading, vision of the past... [Underlining by the writer, EvE]

81 Compare M Adhikari, "Responses to marginality: Twentieth-century coloured politics", South African Historical Journal, 20(1), 1988, pp. 115-125; WH Worger, "White radical history in South Africa", South African Historical Journal, 24(1), 1991, pp. 145-153 (esp. p. 148); CA Hamilton , “'An appetite for the past': The recreation of Shaka and the crisis in popular historical consciousness", 22(1), 1990, pp.141-157.

82 L de Kock, "Contending with the information narrative", South African Historical Journal, 29(1), 1993, pp. 274-282.

83 South African Democracy Education Trust, The road to democracy in South Africa, Volume 1: 1960-1970 (Cape Town, Zebra Press, 2004), pp. 804 (esp. p. 275).

84 Compare CA Hamilton, “'An appetite for the past': The re-creation of Shaka and the crisis in popular historical consciousness", South African Historical Journal, 22(1), 1990”, pp. 141-157; D Wylie, "A dangerous admiration: EA Ritter's Shaka Zulu”, South African Historical Journal, 28(1), 1993, pp. 98-118.

85 G Mersham, "History, television and Shaka Zulu", South African Journal of Cultural History, 5(1), 1990, pp. 10-19 (esp. p. 10). 
Mersham also warns the reader against the "truth of sensation". ${ }^{86}$ Greenstein, on the other hand, reflects the critique of "truth" searched for by Buthelezi from another incontestable angle: ${ }^{87}$

...The scorn scholars like to direct at Buthelezi for daring to venture into the realm of proper historians is thus misplaced. The real interesting question is not whether he deals objectively with history (as if academics do), or has his own agenda (as if academics do not), but how his interpretation of the past resonates with the concerns of his constituency... Shifting the focus of analysis from manipulations and the political interests they serve, to the historical and discursive conditions that make them possible, enables us to grasp how current political and cultural practices are rooted in popular legacies that fall beyond the control of colonial, elite and academic forces. This would mean the reintroduction of history into the picture, since the success of particular inventions would have to be accounted for by their degree of compatibility (or lack thereof) with already existing images of the past. The invention of tradition would no longer be seen as a process that operates in a vacuum, but as deeply rooted in, and constrained by, its historical context.

Apart from the Zulu controversialities, Alan Paton's imaginary, and globally acclaimed work, Cry the beloved country, also relates to another (fictional) element of "truth". Garry Baines comments on Paton's personal reflections on the book: ${ }^{88}$

Alan Paton's Cry, the Beloved Country (1948) is arguably one of the seminal influences on the shaping of mid twentieth-century South African consciousness with regard to the... [imaginary] ...city. In the preface to his acclaimed novel, the author admitted that although 'the story is not true', when considered 'a social record', it was 'the plain and simple truth'. [Underlining by the writer, EvE].

What is of value to note and perhaps is a global reality is that while historians were drilled over time to be uncomfortable to abundantly reach out in the search for an "ultimate truth" and to rather explore multiple memories in many forms, the ideologically locked mind, the perceived stressed, oppressed and deprived members of community urged and acted outspokenly for the truth. Paton's Cry the Beloved Country can be viewed as falling within this ambit.

86 G Mersham, "History, television and Shaka Zulu", South African Journal of Cultural History, 5(1), 1990, pp. 10-19 (esp. p. 13).

87 R Greenstein, "History, historiography and the production of knowledge", South African Historical Journal, 32(1), 1995, pp. 217-232 (esp. pp. 225-226).

88 G Baines, "On location: Narratives of the South African city of the late 1940s and 1950s in film and literature", South African Historical Journal, 48(1), 2003, pp. 35-46 (esp. p. 40); A Paton, Cry, the beloved country (Harmondsworth, 1975 [1948]). Cry, the Beloved Country portrays the harsher realities of segregated urban spaces, as Kumalo moved from the dusty streets of Sophiatown to the leafy suburbs of Johannesburg in search of truth and justice. 
So the globally experienced difficulty among historians grappling with many issues surrounding "historical truth" - which does not necessarily bring one comfortably closer to any acceptable agenda because somewhere a hidden one will be improvised, whether historians thought about it or not. Think, for example, about the thought of the Israeli political scientist academic Pappe who certainly will not be favourable towards multiple diverse histories, because it seems that some (certainly not historians, but experts from other disciplines) feel it's possible to come to a "historical truth". ${ }^{89}$

Reality is that communities, statesmen and producers of History from other disciplines (far, close-by and in one's own country) always had been, and still are, viewed as acceptable historical imaginaries of the past. Furthermore, if a divide between historians of South Africa are still perceived, as is the case between the Historical Association of South Africa (HASA), and the South African Historical Society (SAHS) as in recent times, ${ }^{90}$ then former perceptions (and even stereotypes) may still stand, ${ }^{11}$ which is not conducible to progress to conceptualise "veracity" as an universal moral obligation (to quote White earlier).

\section{Sensitivity with regard to the realities of fact and fiction among educators of History}

Terry Haydn of England's University of East Anglia's School of Education recently observed that, in many countries, "less time and attention is attached to developing students' understanding of the concept of veracity, or 'truthfulness', in the sense of developing in learners the disposition of respect for evidence, open-mindedness, and awareness of the need to appreciate and acknowledge the appropriate knowledge warrant for historical (and present day) claims which are made". ${ }^{92}$

In what sense it will be possible to follow this very historical-minded route in a-historical environments like South Africa, loaded with political attachments, legacies and a limited number of educated learners in History,

89 I Pappe, A History of modern Palestine. One land, two peoples (United Kingdom, Cambridge, 2004) pp. 333.

90 KL Harris, "Warring societies? Towards a community of historians HASA and SAHS (1956-2014)", Historia, 59(2), November 2014, pp. 344-354 (esp. 344).

91 Afrikaner Nationalism has in the past mostly been associated with historical Afrikaans Universities in South Africa while liberal, radical and revisionist ideologies were perceived as associations with mainly historical English universities in South Africa. Also compare with Bill Nasson's remarks in his review of “John Pampallis's foundations of the New South Africa", South African Historical Journal, 26(1), 1992, pp. 236-244.

92 T Haydn, "Veracity: A neglected facet of history education in schools?", Paper, International Committee of Historical Sciences (ICHS), XXIInd Congress, China-Jinan, 23-29 August 2015. 
will be a challenge that will require more discussion than just a paper debate.

To get some notion concerning to what measures the South African Educational system and Higher Education are sensitised towards a view to the value a dealing with the concept of veracity, the following sections will be explorative.

A concise past view ${ }^{93}$ regarding the urge for notions of veracity in history curricula, textbooks and in teaching on higher education level and in schools

During any period of transitional crisis, the meaningfulness of history is always a point of contention. ${ }^{94}$ Cases do exist where History teaching at school level had been abolished in an attempt at pacification. For example, after the Boer defeat in 1902, Lord Milner provisionally prohibited fatherland History in white schools and apparently only allowed British Imperialist History. ${ }^{95}$ However, the opposite is seen in the memoires of the academic HES Fremantle from Oxford, who found himself at the southern tip of Africa from 1899 by becoming involved with the former South African College (currently the University of Cape Town). In his fervent attempts to establish a Chair of History at this College, his views on History teaching for the youth filtered through from time to time. Thus, his sentiments that the youth and communities should be confronted by means of "unbiased" historical content ${ }^{96}$ had a long history and enjoyed a lot of support: ${ }^{97}$

Indeed, the planners of new school syllabi for post-war South Africa argued that the "political attitude" of the next generation would be determined by the History teaching.

In 1902, he presented his views on History teaching and academic research into the history of South Africa of that time, to a select British audience: ${ }^{98}$

93 A more extended view is available in ES van Eeden, "The youth and History - today and yesterday, with reference to the Hertzog era", Hertzog Memorial Lecture, South African Academy for Science and Art, $40^{\text {th }}$ lecture, 21 September 2011, pp. 1-43.

94 G Weldon, "A comparative study on the construction of memory and identity in the curriculum of postconflict societies: Rwanda and South Arica (2003)" (available at http://www.centres.ex.ac.uk/historyresource/ journal11/...), pp. 1-16.

95 FA van Jaarsveld, "Weereens ' $n$ skoongeveegde lei? - Afrekening met, en nuwe singewing aan die Suid-Afrikaanse geskiedenis?”, Historia, 39(1), May 1994, pp. 95-96, 98.

96 RB Mulholland, The evolution of history teaching in South Africa (MEd thesis, University of the Witwatersrand, 1981), p. 127, as cited by H Phillips, "The South African college and the emergence of history as a university discipline in South Africa", Historia, 49(1), May 2004, pp. 1-11.

97 RB Mulholland, The evolution of history teaching in South Africa (MEd thesis, University of the Witwaterrand, 1981), p. 127, H Phillips, "The South African college and the emergence of history as a university discipline in South Africa", Historia, 49(1), May 2004, pp. 1-11.

98 H Phillips, "The South African college and the emergence of history as a university discipline in South Africa", Historia, 49(1), May 2004, p. 7. 
The subject [History] had been neglected with fatal results, and it was an Imperial necessity that this neglect should be corrected. The absence of accurate and unbiased historical knowledge... had allowed political myths to flourish among all the inhabitants of South Africa, and these had to be removed if a new country was to be built on a sound basis. Its bureaucrats too would need such knowledge, while a "scientific" study of the past would be vital for any serious study of "native questions"... as "a work of incomparable importance" for the future...

Commendable views by Fremantle though not necessarily taken seriously by those who should hear. Curriculum debates on what content, for example, suits youth at the FET level best, most of the time results in curriculum debates and suggestions for or against certain themes. ${ }^{99}$ This tendency is not necessarily a negative drift, as excellence is supposed to evolve from constructive critique. However, content selection and method have always been contentious as so many voices and sectors want to be heard to ensure that the "truths" they present are incorporated in history curricula. ${ }^{100}$

Bundy, in 1993, well summarised an ideal approach to the FET history curriculum that hints towards an inclusiveness of diverse truths: ${ }^{101}$

... [to be] concerned with the content and interpretation of South African history, its main emphasis being that history should "reflect advances in the discipline of history". That is: school texts should reflect recent and current debates about the past: the approach to the past should be inclusive and democratic; the approach to historical knowledge should be analytical and explanatory; skills and content should be inseparable so that the curriculum conveys a sense of how knowledge is produced and history not presented as a set of given facts...South African history should reflect the diversity of its population, while also accounting for processes that have created a single society; and should locate the country's history within regional, continental and global events and processes.

A diversity of contributions (in memories) and diverse perspectives (in content) are required in History education in order to limit content distortion (and even to try to avoid it completely) to progress towards a balanced "truth". In South Africa emotions about its past contested any will to ensure a balanced view on a history curriculum, or in school textbooks culminating

99 P Kallaway, "History in Senior Secondary School CAPS 2012 and beyond: A comment", Yesterday\&Today, 7, July 2012, pp. 23-62;

100 Compare B Trabold, "Historical Narratives as a rhetoric of resistance in apartheid South Africa: The History workshop and the new nation", South African Historical Journal, 62(4), 2010, p. 749; P Meyer, Ons geskiedenislose tyd, Historia, 12(7), Mei 1967, pp. 5-6; FA van Jaarsveld, Skoolgeskiedenis in die nuwe SuidAfrika, Gister en Vandag/Yesterday and Today, 20, September 1990, p. 2.

101 View of historian Colin Bundy as quoted in L Chisholm, "Migration, citizenship and South African History textbooks”, South African Historical Journal, 60(3), 2008, pp. 357-358. P Kapp's argument also hints at this. See P Kapp, "Die toekoms van Geskiedenis as skoolvak in Suid-Afrika", Yesterday and Today/Gister en Vandag, 25, May, 1993, pp. 6-7. 
from a revised curriculum. ${ }^{102}$ The post- 1994 transformation of education in South Africa ${ }^{103}$ at especially school level jumbled in high and low moments. Kallaway noted that "The rejection of the apartheid education curriculum in History was confused with the abandonment of a curriculum that was based on historically constructed knowledge". ${ }^{104}$ Curriculum 2005 and Outcomesbased Education reforms, which emphasised "the most radical constructivist curriculum ever attempted anywhere in the world", ${ }^{105}$ allowed for a scenario of historical amnesia: not at all welcomed in a multi-diversified country. The significance of History as a core subject, necessary to be offered in schools, was reaffirmed with the approval of the Curriculum and Assessment Policy Statement (CAPS) for senior high school (Grades 10-12) in 2012. ${ }^{106}$ The new CAPS curriculum was welcomed - its credibility was, however, also questioned in terms of knowledge criteria and pedagogic viability. ${ }^{107}$ Two aspects of the CAPS criticism to be pointed out are based on i) whether "truthfulness" is aspired and ii) whether learners of History are made aware of veracity as a didactic principle in viewing past historical events.

\section{i. Is "truthfulness" demanded and required in CAPS?}

Though more voices of standing should still be heard on this question, the respected impressions of Peter Kallaway must be used as an informative point of departure. In Kallaway's vocabulary, "truthfulness" is embraced in the words "valid claims about the past". While relying on Christine Counsell's (of the United Kingdom) research regarding the history curriculum, ${ }^{108}$ Kallaway states the following about the South African History CAPS:

... the purpose of teaching and learning history in the classroom is to bring the epistemic tradition of history to the pedagogical site so that pupils can understand the grounds on which valid claims about the past can be made...bringing an

102 Compare the comment with the views of R Siebörger and J Reid, "Textbooks and the School History Curriculum”, South African Historical Journal, 33(1), 1995, pp. 169-177.

103 Compare with K Asmal and J Wilmot (Eds.), Spirit of the nation. Reflections on South Africa's educational ethos (Claremont, HSRC, 2002), pp. 2-17; M Khabele, "Political culture and democratic governance in Southern Africa”, African Journal for Political Science, 8(1), 2003, pp. 85-112.

104 P Kallaway, "History in Senior Secondary School CAPS 2012 and beyond: A comment", Yesterday\&Today, 7, July 2012, p. 2 .

105 A quoted by Taylor as cited by W Hugo (2005) as referenced by P Kallaway, "History in Senior Secondary School CAPS 2012 and beyond: A comment", Yesterday\&Today, 7, July 2012, pp. 23-62.

106 ES v an Eeden, "Studying History in South Africa: Reflections of yesterday to face, map and bridging diversity today and tomorrow", E Erdmann and W Hasberg (eds.), Facing - Mapping - Bridging diversity, 2 (Germany, Foundation of European Discourse on History Education), January 2015.

107 P Kallaway, "History in Senior Secondary School CAPS 2012 and beyond: A comment", Yesterday\&Today, 7, July 2012, pp. 23-62.

108 C Counsell, "Disciplinary knowledge for all: The secondary history curriculum and history teachers' achievement”, Curriculum Journal, 22(2), pp. 201-225 (esp p. 202). 
epistemic tradition to the pedagogical site so that pupils can understand the grounds on which valid claims about the past can be made will never be easy...

Yet, it is argued by Counsell and Kallaway, that "good history teaching does foster thinking, reflection, criticality and motivation" ${ }^{109}$

Kallaway continues to note his concern about topics four to six of Grade 12 (see diagram below):

My real concerns lie with Gr. 12: Topics 4, 5 and 6, which might well be very important and interesting for students to know and grapple with on grounds of relevance or political education, but the difficulties of relating this material to "the epistemic tradition of (historical studies) so that pupils can understand the grounds on which valid claims about the past can be made"... [it] would seem to be... impossible in this context.

\begin{tabular}{|c|l|}
\hline $\begin{array}{c}\text { TOPIC } \\
\text { NO }\end{array}$ & GRADE 12 \\
\hline $\mathbf{1}$ & $\begin{array}{l}\text { The Cold War: Origins of the Cold War; Extension of the Cold War; Case study: } \\
\text { China OR Vietnam; Stages in the war. }\end{array}$ \\
\hline $\mathbf{2}$ & $\begin{array}{l}\text { Independent Africa: What were the ideas that influenced independent states? } \\
\text { Comparative case studies: the Congo and Tanzania; The successes and challenges faced } \\
\text { by independent Africa? What was the impact of the internal and external factors on } \\
\text { Africa during the time? Africa in the Cold War: Case study: Angola. }\end{array}$ \\
\hline $\mathbf{3}$ & $\begin{array}{l}\text { Civil Society protests 1950s to 1970s: Overview of civil society protests; Case study: } \\
\text { the US Civil Rights Movement; Case Study: the Black Power Movement. }\end{array}$ \\
\hline $\mathbf{5}$ & $\begin{array}{l}\text { Civil resistance in South Africa 1970s to 1980s: The challenge of Black consciousness } \\
\text { to the Apartheid state; The crisis of Apartheid in the 1980s: Government attempts to } \\
\text { reform Apartheid; Internal resistance to reforms: International response; The beginning } \\
\text { of the end. }\end{array}$ \\
\hline $\mathbf{6}$ & $\begin{array}{l}\text { The coming of democracy in South Africa and coming to terms with the past: The } \\
\text { negotiated settlement and the Government of National Unity; How has South Africa } \\
\text { chosen to remember the past? The Truth and Reconciliation Commission: Reasons for } \\
\text { the TRC; Remembering the past: memorials. }\end{array}$ \\
\hline $\begin{array}{l}\text { The end of the Cold War and a new world order: The end of the Cold War: the events } \\
\text { of 1989; A new world order: Globalisation; responses to globalisation; unfinished } \\
\text { process of liberation in South Africa. }\end{array}$ \\
\hline
\end{tabular}

The only reference to "truth" in the CAPS document relates to the Truth and Reconciliation Commission's work as a way of remembering the past as outlined as Topic Five in the Grade 12 Curriculum. To aim towards a "truthful"

109 P Kallaway, "History in Senior Secondary School CAPS 2012 and beyond: A comment", Yesterday\& Today, 7, July 2012, pp. 23-62. 
topic reflection, the CAPS-curriculum content outline offers limited bits of possibilities with the intention to allow for the conceptualising of multiple perspectives. ${ }^{110}$ Topics three and four of the Grade 12 Curriculum combined may be used as an example to encourage multiple diverse perspectives, and also the following topics in the curriculum outline of other grades:

\begin{tabular}{|c|l|}
\hline GRADE & TOPIC \\
\hline 7 & $\begin{array}{l}\text { The transatlantic slave trade: The impact of the transatlantic slave trade on the } \\
\text { economies of West Africa, America and Britain; Gains for America and }\end{array}$ \\
\hline 10 & $\begin{array}{l}\text { The world around 1600: Broad comparative overview: China; Songhai; India } \\
\text { (Mughal); European societies }\end{array}$ \\
\hline 11 & $\begin{array}{l}\text { Ideas of race in the late 19th and 20th centuries: Theories and Practice; Case study: } \\
\text { Australia and the Indigenous Australians; Case study: Nazi Germany and the } \\
\text { holocaust. }\end{array}$ \\
\hline
\end{tabular}

ii. Are learners of History made aware of veracity as a didactic principle in viewing past historical events?

Though the curriculum as represented in the CAPS remain the core guideline to address the themes and topics outlined, the initiative and creativity to encourage diversity and diverse perspectives on each topic will still remain the responsibility of educators. In the CAPS guidelines support is expressed for rigorous historical enquiry by means of, amongst others, "historical truth that consists of a multiplicity of voices expressing varying and often contradictory versions of the same history". ${ }^{11}$ That is where the "support" stops. Textbooks (the few of them approved in South Africa nowadays) also do not necessarily offer sufficient guidance and insight since they are most of the time created and produced within short spaces of time with limited input from experts knowledgeable on a specific topic. ${ }^{112}$ In this regard, the responsibility is that of Higher Education and Training Institutions that will have to train prospective educators more efficiently in dealing meaningfully with "truth" and "truthfulness" as a means to complement diverse knowledge pools of identity and memory on the same topic. An encouragement to work towards valid, reliable and authentic pools of reality will nurture ideals of establishing the ideal meaning of veracity in the classroom. ${ }^{13}$ In the eight CAPS criteria - as principles to progress towards veracity - it is certainly high on the agenda (see table below regarding articulations suggesting openness

110 ES van Eeden sources.

111 Republic of South Africa, Department of Education, National Curriculum Statement, Curriculum and Assessment Policy Statement, Further Education and Training Phase (Grades 10-12, History, 2012), pp. 5-6.

112 P Kallaway source.

113 ES van Eeden, "The youth and school history-learning from some of the thinking of yesterday in South Africa", Yesterday\&Today,8, 2012, pp. 23-46. 
and inclusivity), ${ }^{114}$ but whether these are properly addressed in South Africa's textbooks for schools (and currently in the very limited number of textbooks allowed per grade) is a debate for another day:

\footnotetext{
$\checkmark$ Social transformation: ensuring that the educational imbalances of the past are redressed, and that equal educational opportunities are provided for all sections of the population;

$\checkmark$ Active and critical learning: encouraging an active and critical approach to learning, rather than rote and uncritical learning of given truths;

$\checkmark$ High levels of knowledge and high skills levels: the minimum standards of knowledge and skills to be achieved in each grade are specified and set high, achievable standards in all subjects;

$\checkmark$ Progression: content and context of each grade show progression from simple to complex;

$\checkmark$ Human rights, inclusivity, environmental and social justice: infusing the principles and practices of social and environmental justice and human rights as defined in the Constitution of the Republic of South Africa;

$\checkmark$ The National Curriculum Statement for Grades R-12 is sensitive to issues of diversity such as poverty, inequality, race, gender, language, age, disability and other factors;

$\checkmark \quad$ Valuing indigenous knowledge systems: acknowledging the rich history and heritage of this country as important contributors to nurturing the values contained in the Constitution; and

$\checkmark$ Credibility, quality and efficiency: providing an education that is comparable in quality, breadth and depth to those of other countries.
}

Choices, with regard to the content of History education in the past and the inclusion of a range of experts in History, did not really set this example, ${ }^{115}$ and that is why any clear expectations regarding multi-perspective History education ${ }^{116}$ at school level in the early 21 st century have hardly been possible to

114 Republic of South Africa, Department of Education, National Curriculum Statement, Curriculum and Assessment Policy Statement, Further Education and Training Phase (Grades 10-12, History, 2012), pp. 5-6.

115 Compare Human Sciences Research Council (HSRC), "Die onderrig van geskiedenis aan Suid-Afrikaanse sekondêre skole; 'n Volledige weergawe van 'n opname in die jaar 1966”, Compiler CR Liebenberg, Report 0-11, RGN, Pretoria, 1971, pp. 1-304. From pp. 234 it is pointed out that History as subject is losing popularity due to poor teaching; repetitive content; poor remuneration of teachers; spoon-feeding at school and the so-called "worthlesness" of History; P Kallaway, "History education in a democratic South Africa", Yesterday and Today/ Gister en Vandag, 26 October 1993, pp. 10-17; L Chisholm, "Migration, citizenship and South African History textbooks", South African Historical Journal, 60(3), 2008, p. 357; P Kallaway, "History in Senior Secondary School CAPS 2012 and beyond: A comment”, Yesterday\&Today, 7, July 2012, pp. 23-62.

116 Not all History educators and historians understood the concept in the same multi-perspective way, therefore division sprouted from that for a while as well. See P Kallaway, "History education in a democratic South Africa", Yesterday and Today/Gister en Vandag, 26 October 1993, pp. 10-17; MH Trümpelmann, "The HRSCinvestigation on history teaching - a response", Yesterday and Today/Gister en Vandag, 23 May 1992, pp. 46-49. 
date, ${ }^{117}$ and will probably continue to be impossible if the protocol remains. ${ }^{118}$ This setting is not conducive to progress towards notions of complimenting the urge for truthfulness or veracity. A way that educators can explore to deal with creating a sense of the value veracity in research and teaching is to engage more constructively in critical reading of scientific created sources.

\section{Equipping the educator with a tool to critically assess truthfulness in historical sources}

A possible way to address the complexity and difficulty of dealing with and working towards truthful historical accounts is to develop educational criteria to meaningfully assess research produced. A possibility to depart from can be viewed in the example to follow. Its use at the North-West University in South Africa for several years has now made undergraduate and postgraduate students more sensitive to their own style of writing while simultaneously honing their skills with regard to reading and interpreting scientific articles. There is no reason why learners in lower grades (at school level) cannot be exposed to some of these criteria as proposed in the grid to follow (and to other criteria as well that educators of History may feel necessary to use):

\footnotetext{
Critical reading in classrooms (for Educators of History)

CRITICAL READING ASSESSMENT CRITERIA

When critical reading is required, the questions below all apply to the source(s), as indicated, selected or as advised. ALL questions below must receive attention in critical reading, even if you are not able to find any application in the sourceltext selected for perusal.

[Please clearly indicate the page, paragraph and words you are referring to regarding a specific reader. State the title of the reader as well.]

\section{ANSWER THE FOLLOWING QUESTIONS ON PAPER. NUMBERING MUST BE DONE VERY} ACCURATELY. Respond in full sentences:

1) In half a page (or less), a) summarise the content of the source being studied, [4] and b) the value you observe coming forth from having read it (if any). [2]

2) Identify six remarks in the source that, via your research, appear to be based on factual evidence. (Indicate page, paragraph and the line PLUS write down the sentence and underline the part you refer to.) [6]

3) Identify two remarks in the source text that appear to be based on opinion(s) (based on research or in general and clearly indicate which of the two). (Indicate page, paragraph and the line PLUS write down the sentence and underline the part you refer to.) [2]
}

117 Compare P Kapp, "Die toekoms van Geskiedenis as skoolvak in Suid-Afrika”, Yesterday and Today/Gister en Vandag, 25 May 1993, pp. 3-15; BC Mohamed, "Alternative history as a response to multi-culturalism in History teaching", Yesterday and Today/Gister en Vandag, 21 April 1991, pp. 24-26; WRL Gebhard, "Does history teaching ask and answer relevant questions in a multi-cultural society?: Some suggestions for enlarging the vision of History", Yesterday and Today/Gister en Vandag, 22 September 1991, pp. 1-12; P Kapp, "Culture context and historical text”, Yesterday and Today/Gister en Vandag, 26 October 1993, pp. 4-9.

118 Based on the author's personal experience as chairperson of the Society for History Education in South Africa and personal endeavours with regard to criticism relating to the latest History curriculum for the general and further education teaching phase, including the manner of secrecy and poor handling of the latest process in school textbook development for learners of History. 
4) Identify any words that the author uses (or the authors use) that appear to be applied by the author(s) as a means to exaggerate or serve the purpose of using adjectives for a more "lively" presentation. (Motivate your response, even if you are unable to identify any such use of words.). PLEASE submit the page number and full sentence of each example identified. [2]

5) Writing style: How does the author overcome [FULL sentences please. Not only a "no" or "yes" Motivate your every response.]:

5.1) Historical silences in the content with which he or she is dealing? [2]

5.2) His or her uncertainty about issues? (Identify, e.g., the use of words such as "perhaps", "maybe", "possible" "there", "also", as well as "some people/individual/person", etc.). [2]

6) Were you able to pick up words or sentences that cultivate or may cultivate IFULL sentences please. Nor merely a "no" or "yes" Motivate your response and underline the part of the sentence which you think applies AND also refer to the page, the paragraph, as well as the line]:

6.1) Stereotyping/Labelling [1]

6.2) Bias [1]

6.3) Racism [1]

6.4) Any perception of whatever nature (e.g. gender preferences or generalisations (such as "it is clear" or "it is obvious"). [1]

7) Based on all your impressions above, do you think that the author (or authors) succeeded in:

7.1) Using all available sources effectively? [1]

7.2) Exploring any other possible appropriate sources that might have been explored? (This question requires you to explore information system networks for other possible applicable sources if you have actually identified possible shortcomings.) [3]

7.3) Does the author's article serve as an objective and fair overview to the readers with regard to the theme discussed? [2]

\section{Recapping and assessing}

That a search for a complete "truth" in writing histories will always imply partiality and seems to be fait accompli, and not contested. In History no historical discussion is definite or final for Marwick and most historians will probably agree. The debate can always be qualified or corrected and political bias will be pointed out vigorously. Marwick also points out that historians are not propagandists. Their "job" is to understand the past (or parts of it), to inform and not "to change the future".

From this perspective of the historical battle, one may even add whether - in the possible absence or total lack of a more inclusive use of past recounts in their variety (multi-disciplines) and diversity (several voices and traditions) - the need for sensitivity regarding the use of words like "integrity" and "veracity" will not bring about increasing remoteness and distance.

It will be a special day if historians and educators of History aspire to produce all-inclusive reflections on a past (in writing and in teaching). An engagement with the past may also differ in certain timeframes as more or 
additional information on the past is exposed, discovered or reinterpreted with the support of "other" sources providing more detail as additional insight. An escape from fiction or a lack of truthfulness in everyday life with its spontaneously growing paradigms and ideologies made by anyone in any profession is hardly imaginable. Yet a more informed and critical stand could be manageable in the education process (and by historians) if a dealing with a past is engaged with historically: Which implies a moral obligation towards inclusiveness and reflectiveness as part of progressing towards being truthful. 